\begin{tabular}{|c|c|c|c|}
\hline \multirow{3}{*}{$\begin{array}{r}\text { Case Reports in } \\
\text { Gastroenterology }\end{array}$} & \multirow{2}{*}{\multicolumn{2}{|c|}{ Case Rep Gastroenterol 2016;10:629-632 }} & \multirow[b]{3}{*}{$\begin{array}{l}\text { Karger } \\
\text { Open'access }\end{array}$} \\
\hline & & & \\
\hline & $\begin{array}{l}\text { DOI: 10.1159/000452212 } \\
\text { Publisned oninne: October 28, } 2016\end{array}$ & $\begin{array}{l}\text { (c) } 2016 \text { The Author(s) } \\
\text { Published by S. Karger AG, Basel } \\
\text { www.karger.com/crg }\end{array}$ & \\
\hline & $\begin{array}{l}\text { This article is licensed under the } \\
\text { International License (CC BY-NC) } \\
\text { Usage and distribution for commerci }\end{array}$ & $\begin{array}{l}\text { nons Attribution-NonCommercial } 4.0 \\
\text { ger.com/Services/OpenAccessLicense). } \\
\text { uires written permission. }\end{array}$ & \\
\hline
\end{tabular}

\title{
Intestinal Bacterial Infection Diagnosed by Histological Examination of Endoscopic Biopsy Specimens
}

\author{
Michiko Yuki Yuko Emoto Katsuhiko Yoshizawa Takashi Yuri \\ Airo Tsubura \\ Department of Pathology II, Kansai Medical University, Hirakata, Japan
}

\section{Keywords}

Intestinal infection · Bacteria · Biopsy · Immunohistochemistry

\begin{abstract}
Intestinal spirochetosis (IS) in humans is characterized by spirochetal microorganisms attached to the luminal surface of the colonic epithelium. In the present case, attached organisms appeared as 3- to $4 \mu \mathrm{m}$-thick (average thickness, $3.4 \mu \mathrm{m}$ ) basophilic fringes or haze in $\mathrm{HE}$-stained endoscopic biopsy specimens. The basophilic fringes were clearly labeled by Treponema pallidum antiserum. Because IS is relatively rare in developed countries, thin basophilic fringes characteristic of IS are readily overlooked. Thus, the recognition of histological characteristics of this disease is important for its diagnosis.

(C) 2016 The Author(s)

Published by S. Karger AG, Basel
\end{abstract}

\section{Introduction}

Intestinal spirochetosis (IS) in humans is a rare disease in which the spirochetes species, coiled Gram-negative bacteria with flagella, infects the gastrointestinal tract. Spirochetes are divided into the Spirochaetaceae, Leptospiraceae, and Brachyspiraceae families. Two members of the Brachyspiraceae family, Brachyspira aalborgi and B. pilosicoli, are commonly as- 
Yuki et al.: Intestinal Bacterial Infection Diagnosed by Histological Examination of Endoscopic Biopsy Specimens

sociated with human IS [1]. B. pilosicoli is a pathogen of the large intestine in various animal species including humans, while B. aalborgi has only been found in macaques and humans [2]. In the present report, a case of IS was diagnosed by histological examination of endoscopic biopsy specimens.

\section{Case Report}

A 61-year-old man was clinically diagnosed with colitis and underwent endoscopic examination. A colonoscopy revealed scattered varioliform erosions from the ileum end to the rectum. Clinical records indicated that the same colonoscopic findings were seen 4 years ago, and according to the corresponding pathology report, nonspecific colitis was the pathological diagnosis. However, further clinical information regarding the previous colonoscopic findings was unavailable. A differential diagnosis to exclude inflammatory bowel disease and amebic dysentery was required.

Biopsy specimens during endoscopy were taken from the ileum end, ascending colon, and sigmoid colon. In HE-stained sections, all specimens showed marked but nonspecific inflammatory cell infiltration in the mucosal layer. The histology did not support a diagnosis of inflammatory bowel disease, such as Crohn's disease or ulcerative colitis. Moreover, PASstained sections did not label trophozoites, so amebic colitis was excluded. However, specimens from the sigmoid colon displayed characteristic morphology, so-called basophilic fringes, haze, or false brush border on the luminal surface and in the crypts of the nonneoplastic epithelium, suggestive of IS (Fig. 1a). Invasion of the microorganism beyond the surface epithelium was not seen in biopsy specimens. The IS infection was confirmed by immunostaining with antiserum against Treponema pallidum (rabbit polyclonal antibody; Biocare Medical, Concord, CA, USA), performed according to the manufacturer's instructions (Fig. 1b). This antiserum clearly labels Brachyspiraceae [3]. Therefore, infective colitis associated with IS was the diagnosis.

To measure the thickness of the fringes on the luminal surface, HE-stained and immunostained slides were scanned with a high-resolution digital scanner (NanoZoomer 2.0 Digital Pathology; Hamamatsu Photonics, Hamamatsu, Japan) to prepare digital images. The NDPI image files were opened in color mode with NDP.view software (Hamamatsu Photonics). The images were converted to JPEG files at $\times 400$ magnification in 10 randomly selected areas within each slide. The microorganism thickness was 3-4 $\mu \mathrm{m}$ (average, $3.4 \mu \mathrm{m}$ ).

\section{Discussion}

Human IS was first described by Harland and Lee in 1967 [4]. IS has been linked to diarrheal illness in swine, poultry, dogs, cats, opossum, guinea pigs, and nonhuman primates [1]. In contrast, IS in humans is typically asymptomatic; if symptoms are present in humans, the most common symptoms are diarrhea and abdominal pain $[1,3,5]$. In the present case, infective colitis associated with IS [6] was the pathological diagnosis. The incidence of IS is 2$7 \%$ in Western countries and $11-34 \%$ in less-developed countries; the incidence of IS in Japan is $0.4 \%$ [5]. However, the incidence of IS is up to $54 \%$ in homosexual men and HIVpositive patients [5]. IS should be considered to be an opportunistic infection in immunodeficient patients. Both adult and pediatric cases have been reported [7].Transmission generally occurs by the fecal-oral route (exposure to contaminated water and/or contact with 
Yuki et al.: Intestinal Bacterial Infection Diagnosed by Histological Examination of Endoscopic Biopsy Specimens

infected animals, potential for zoonotic spread), but sexual transmission does occur in homosexual men [7].

The endoscopic appearance of IS is polypoid, erythematous, or normal, but it does not display pathognomonic changes that would aid in its diagnosis [1]. The diagnosis of IS is made exclusively from the histological examination of endoscopic biopsy specimens. IS is characterized by spirochetal microorganisms adherent to the surface of the intestinal mucosa; these appear as basophilic fringes or haze on HE-stained sections. However, due to the rarity of the disease, thin basophilic fringes are readily overlooked. To more clearly visualize the basophilic fringes, Warthin-Starry silver stain, Giemsa stain, and PAS stain are useful. Members of the Brachyspiraceae family are morphologically similar to other spirochetes and cross-react with antitreponemal serum and antileptospiral serum [3, 5, 8]. Immunostaining with these sera is an easy method that yields reproducible and reliable results for the identification and definitive diagnosis of IS. By electron microscopy, the basophilic fringes seen in light microscopy consist of dense spirochetes with flagella between the microvilli that perpendicularly adhere to the intestinal epithelial membrane $[1,9,10]$. In contrast, to detect attached microorganisms in fixed sections, imprint cytology detects floating microorganisms [10].

The causative spirochetes in humans are B. aalborgi and B. pilosicoli. B. aalborgi is the most prevalent species in Western countries and Japan, while B. pilosicoli infection is prevalent predominantly in less-developed countries and may be more common in HIV-positive patients $[3,5,10]$. The two species can be differentiated by PCR-based genotyping [2] and a serological agglutination test [11]. The mean length of $B$. aalborgi is $3.8 \mu \mathrm{m}$ (range, 2-4.5 $\mu \mathrm{m}$ ), which is significantly shorter than that of B. pilosicoli (mean, $5.5 \mu \mathrm{m}$; range, 3.2-11 $\mu \mathrm{m}$ ) [3]. Genotyping was not performed in the present study, but the mean length of the microorganisms measured during light microscopy was consistent with that of B. aalborgi. Although the patient's immune status is unknown, B. aalborgi is commonly found in the nonhomosexual Japanese population [5]. In general, $B$. aalborgi is considered to be nonpathogenic, but the invasion of the microorganism beyond the surface epithelium may be associated with gastrointestinal symptoms [1]. IS was previously found exclusively in nonneoplastic epithelium and hyperplastic epithelium but not in adenomatous or carcinomatous epithelium [5]. However, some adenomas support the growth of IS [12,13]. Therefore, biopsies for histological diagnosis can be made from both nonneoplastic epithelium and neoplastic epithelium. For IS therapy, metronidazole treatment consisting of $500 \mathrm{mg} 3$ times a day for 10 days in adults and $15 \mathrm{mg}$ per kg body weight 3 times per day for 5 days in children has been reported to eradicate IS symptoms [7].

In conclusion, as IS is relatively rare in developed countries, the histological recognition of this disease is important for its pathological diagnosis.

\section{Statement of Ethics}

The authors have no ethical conflicts to disclose.

\section{Disclosure Statement}

The authors declare no conflicts of interest. 
Yuki et al.: Intestinal Bacterial Infection Diagnosed by Histological Examination of Endoscopic Biopsy Specimens

\section{References}

1 Tsinganou E, Gebbers JO: Human intestinal spirochetosis - a review. Ger Med Sci 2010;8:DOC1.

-2 Mikosza AS, La T, de Boer WB, Hampson DJ: Comparative prevalences of Brachyspira aalborgi and Brachyspira (Serpulina) pilosicoli as etiologic agents of histologically identified intestinal spirochetosis in Australia. J Clin Microbiol 2001;39:347-350.

-3 Tateishi Y, Takahashi M, Horiguchi S, Funata N, Koizumi K, Okudela K, Hishima T, Ohashi K: Clinicopathologic study of intestinal spirochetosis in Japan with special reference to human immunodeficiency virus infection status and species types: analysis of 5265 consecutive colorectal biopsies. BMC Infect Dis 2015;15:13.

4 Harland WA, Lee FD: Intestinal spirochaetosis. Br Med J 1967;3:718-719.

-5 Tanahashi J, Daa T, Gamachi A, Kashima K, Kondoh Y, Yada N, Yokoyama S: Human intestinal spirochetosis in Japan; its incidence, clinicopathologic features, and genotypic identification. Mod Pathol 2008;21:76-84.

6 Calderaro A, Bommezzadri S, Gorrini C, Piccolo G, Peruzzi S, Villanacci V, Zambelli C, Dettori G, Chezzi C: Infective colitis associated with human intestinal spirochetosis. J Gastroenterol Hepatol 2007;22:17721779.

-7 Helbling R, Osterheld MC, Vaudaux B, Jaton K, Nydegger A: Intestinal spirochetosis mimicking inflammatory bowel disease in children. BMC Pediatr 2012;12:163.

-8 De Brito T, Sandoval MP, Silva AG, Saad RC, Colaiacovo W: Intestinal spirochetosis: first cases reported in Brazil and the use of immunohistochemistry as an aid in histopathological diagnosis. Rev Inst Med Trop Sao Paulo 1996;38:45-52.

9 Guccion JG, Benator DA, Zeller J, Termanini B, Saini N: Intestinal spirochetosis and acquired immunodeficiency syndrome: ultrastructural studies of two cases. Ultrastruct Pathol 1995;19:15-22.

10 Ogata S, Higashiyama M, Adachi Y, Ohara I, Nishiyama J, Okusa Y, Takeo H, Sato K, Nakanishi K, Kawai T: Imprint cytology detects floating Brachyspira in human intestinal spirochetosis. Hum Pathol 2010;41:249-254.

-11 Abe Y, Hirane A, Yoshizawa A, Nakajima H, Adachi Y: The specific antibody to Brachyspira aalborgi in serum obtained from a patient with intestinal spirochetosis. J Vet Med Sci 2006;68:1089-1091.

12 Higashiyama M, Ogata S, Adachi Y, Nishiyama J, Ohara I, Okamura M, Matsuzaki K, Okusa Y, Sato K, Hokari R, Miura S: Human intestinal spirochetosis accompanied by human immunodeficiency virus infection: a case report. Acta Med Okayama 2009;63:217-221.

-13 Carr NJ, Mahajan H, Tan KL, Sharma R: The histological features of intestinal spirochetosis in a series of 113 patients. Int J Surg Pathol 2010;18:144-148.
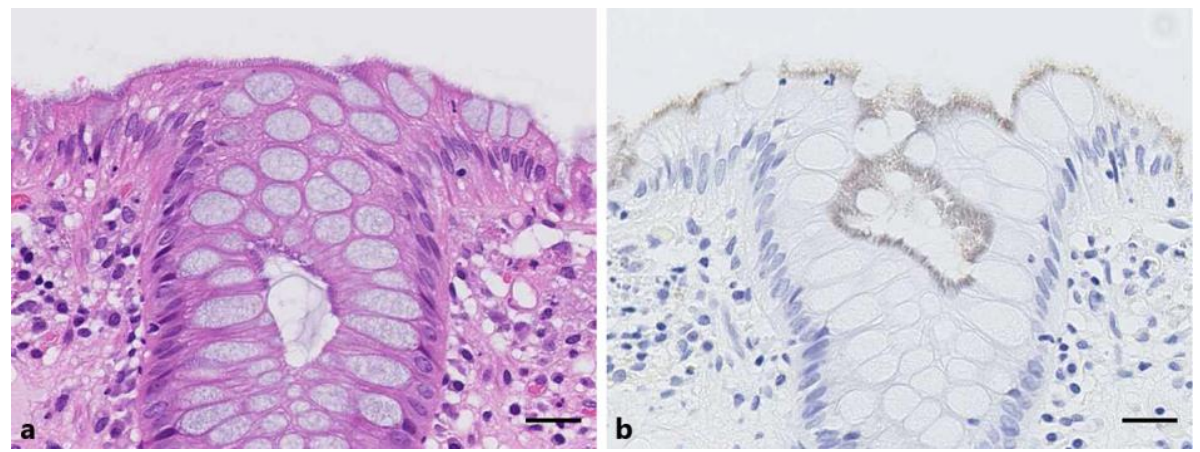

Fig. 1. Intestinal spirochetosis. a Basophilic fringes (average thickness, $3.4 \mu \mathrm{m}$ ) reflecting a group of spirochetes are seen on the luminal surface of sigmoid colon mucosa by HE staining. $\mathbf{b}$ Immunostaining with T. pallidum antiserum highlights the fringes. Scale bars, $25 \mu \mathrm{m}$. 